\title{
Infectious Encephalitis
}

National Cancer Institute

\section{Source}

National Cancer Institute. Infectious Encephalitis. NCI Thesaurus. Code C79550.

An acute infectious process that affects the brain tissue. It is usually caused by viruses and less often by bacteria, parasites, and fungi. 